\title{
Ripening effects on the chilling sensitivity of processing and non-processing tomato cultivars
}

\author{
M. Mohammed and R.A.I. Brathwaite
}

Department of Food Production, Faculty of Agriculture and Natural Sciences. The University of the West Indies, St. Augustine. Trinidad, West Indies

\begin{abstract}
Studies on the sensitivity to chilling injury $(\mathrm{Cl})$ of 8 processing and 8 non-processing tomato cultivars stored at the table-ripe stage were examined. Fruits were stored for 21 days at $7^{\circ} \mathrm{C}$ and upon transfer to $20^{\circ} \mathrm{C}$ for 1 or 3 days, respectively. The low correlation coefficient between pitting and decay suggested that these two early manifestations of $\mathrm{Cl}$ are not significantly related. The least sensitive tomato cultivars to $\mathrm{Cl}$ were Advantage, Dorado and Rio Grande among the processing types and Star Pak and Walters of the non-processing types. The least tolerance to $\mathrm{Cl}$ were processing cultivars Caraibe and Cascade and non-processing cultivars Early Set, Carnival and Capitan. The observed tolerance of table-ripe tomatoes mentioned above after 21 days at $7^{\circ} \mathrm{C}$ plus 3 days at $20^{\circ} \mathrm{C}$ compared to control fruit stored continuously at $20^{\circ} \mathrm{C}$ for only $8-11$ days, indicates that a longer marketing period could be obtained at tempertures lower than those currently recommended.
\end{abstract}

Key words: Tomato, processing and non-processing cultivars, chilling injury, sensitivity

\section{Introduction}

Chilling injury (CI) is an economically important postharvest problem that reduces the overall quality and marketability of many harvested fruits and vegetables indigenous to the tropics and subtropics (Couey, 1982, Saltveit and Morris, 1990; Cabrera and Salveit, 1992). The effect of storage temperature on chillinginduced quality changes in tomatoes (Lycopersicon esculentum, Mill.) varies with cultivar (Abou-Aziz et al., 1976), duration of storage (Hobson, 1981) and ripeness of the fruit (Autio and Bramlage, 1986). Ripening-related changes in chilling sensitivity are common among fruit species such as Honey Dew melons (Lipton, 1978), mangoes (Mukerjee and Srivastava, 1979, Mohammed and Brecht, 1999), and papayas (Nazeeb and Broughton, 1978). Most field-grown tomatoes are commercially harvested at the mature-green stage and, thus, much of the previous research on $\mathrm{CI}$ in tomatoes has been conducted with the maturegreen fruit (King and Ludford, 1983; McColloch and Worthington 1952; Buescher, 1974; Thorne and Alvarez, 1982). The objective of this study was to investigate the chilling sensitivity of several table-ripe processing and non-processing tomato cultivars.

\section{Materials and methods}

Field-grown mature-green tomatoes, (Lycopersicon esculentum, Mill.) were hand-harvested at the University Field Station, Valsayn in the dry-season (May - April) and wet-season (July - September) of 1992. Maturity of mature-green fruit was determined in the field using subjective evaluations of fruit size, position on plant, smootheness of fruit shoulder and by observation of locular development in some representative fruit (Kader and Morris, 1975).

Eight processing cultivars, Dorado, Advantage, Peto 94C, Neema 1401, Caraibe, Rio Grande, Donore and Cascade were studied. The eight non-processing cultivars studied were Calypso, Floradade, Floradel, Early Set, Star Pak, Carnival, Walters and
Capitan. Samples from all sixteen cultivars were ripened to tableripe stage, USDA score 6 (United Fresh Fruit and Vegetable Assn., 1975), at $20-22^{\circ} \mathrm{C}$ and $85-90 \%$ RH over 3-4 days. Measurements were made on five fruits per cultivar each time, i.e. after 21 days at $7^{\circ} \mathrm{C}$ (SRI) and upon transfer to $20^{\circ} \mathrm{C}$ for 1 day (SR2) or 3 days (SR3), respectively. Likewise, a similar portion of fruit per cultivar was stored at $20^{\circ} \mathrm{C}$ as the control.

The severity of pitting and decay was determined subjectively on a 8-point hedonic scale as previously described (Cabrera and Saltveit, 1992). The scoring system was $0=$ no pitting or decay ( $0 \%$ of the fruit surface was pitted or decayed, $2=$ slight $(1 \%$ to $5 \%), 4=$ moderate ( $6 \%$ to $15 \%), 6=$ severe $(16 \%$ to $75 \%)$, and $8=$ very severe $(>75 \%)$.

Resistance of the fruit to chilling injury was ranked for each cultivar on a scale of $1-10$ with $1=$ most susceptible and $10=$ most resistant (Cabrera and Saltveit, 1992). The overall quality, based on the general appearance of the fruit, was measured subjectively on a 8point hedonic scale where $0=$ poor (extremely defective), $2=$ fair (defective), $4=\operatorname{good}($ moderately defective), $6=$ very good (slightly defective), $8=$ excellent (not defective).

Brown discolouration on fruit skin indicative of chilling injury was scored on a 5-point hedonic scale where $0=$ no discolouration, $1=$ 0 - $10 \%$ discolouration, $2=11-20 \%$ discolouration, $3=21-40 \%$ discolouration, $4=41-60 \%$ discolouration and $5=>60 \%$ discolouration.

Because of very small and insignificant differences between dry and wet season data, the mean for both the seasons were calculated for each cultivar. Data were subjected to analysis of variance.

\section{Results and discussion}

The severity of pitting depended on cultivar, ranging from 0.0 to 6.7 in fruit stored for 21 days at $7^{\circ} \mathrm{C}$ and kept for an additional 1 or 
3 days at $20^{\circ} \mathrm{C}$ (Table 1). Processing cultivars Advantage and non-processing cultivar Walters developed no pits after 21 days at $7^{\circ} \mathrm{C}$, while processing cultivars Dorado, Rio Grande and Donore and non-processing cultivar Star Pak developed slight pitting under the same storage conditions (Table 1). The most pitted fruits were Peto 94C, Cascade, Neema 1401 and Caraibe (processing) as well as Calypso and Floradade (non-processing) with ratings being 3.4 to 3.8. Likewise, non-processing cultivars Early Set, Carnival and Capitan had pits with ratings above 4.1 after 21 days at $7^{\circ} \mathrm{C}$ (Table 1). Significant increases in pitting between storage regimes SR1 and SR 2 were obtained for $50 \%$ of the processing cultivars (Dorado, Peto 94C, Neema 1401 and Caraibe) and just 25\% for nonprocessing cultivars Calypso and Floradel. However, between SR2 and SR3 pitting progressed significantly for all sixteen cultivars.

Although decay followed a similar trend like pitting between each storage regime (SR1, SR2 and SR3), the correlation coefficient between pitting and decay was low and not significant $(r=0.44)$. Decay ratings for Dorado, Advantage and Rio Grande varied between 2.4 to 2.6 after 21 days at $7^{\circ} \mathrm{C}$ plus 3 days at $20^{\circ} \mathrm{C}$ with fruits showing relatively high resistance to chilling injury (CI) and values ranging from 8.8-9.0 (Table 1). Similar findings were obtained for non-processing cultivars Star Pak and Walters with decay ratings of 3.6 and chilling injury resistance scores of 9.0 9.1 (Table 1). Cultivars with the least resistance to chilling injury were Caraibe, Cascade, Early Set, Carnival and Capitan (Table 1). Meanwhile, control fruit stored continuously at $20^{\circ} \mathrm{C}$ showed no pitting nor chilling injury symptoms as expected, but nevertheless, had an abbreviated shelf life of 8-11 days depending on cultivar, due to overripening and decay.

The high resistance to chilling injury for processing and nonprocessing cultivars mentioned above is consistent with high quality ratings from the time fruit were assessed after 21 days at $7^{\circ} \mathrm{C}(\mathrm{SR} 1)$ and then after 21 days at $7^{\circ} \mathrm{C}$ plus 3 days at $20^{\circ} \mathrm{C}$ (SR3) (Table 2).
Although quality of the non-processing cultivars Star Pak and Walters averaged the same as the processing cultivars Dorado, Advantage, Rio Grande and Donore at SR1, quality evaluations at SR3 showed that Star Pak and Walters secured higher ratings than either of the 4 processing cultivars Advantage, Dorado, Rio Grande and Donore (Table 2).

The correlation between pitting and decay was lower $(r=0.44)$ than between decay and quality $(r=0.79)$. However, pitting is more closely related to fruit resistance to chilling and degree of brown discolouration ( $\mathrm{r}=0.90$ and 0.84 , respectively) than it is to decay $(r=0.46)$. A multiple regression analysis was performed with the percent change in quality as the dependent variable and pitting, decay, fruit resistance to chilling injury and degree of brown discolouration as the independent variables. The analysis produced a coefficient of determination of 0.84 , which suggested that quality after chilling was not only related to pitting and decay, but also to the resistance of the fruit to chilling and the incidence of brown discolouration. Patches of brown stains randomly located on pitted and non-pitted areas against the red fruit skin background were observed for those cultivars with moderate to severe chilling injury. The decline in chilling sensitivity of some of the tomato cultivars highlighted above might be due to changes in endogenous $\mathrm{C}_{2} \mathrm{H}_{4}$ levels. In other studies, Kader and Morris (1975) found that $\mathrm{C}_{2} \mathrm{H}_{4}$ treatment of mature-green and breaker tomatoes did not affect chilling sensitivity. Perhaps other hormones or the interaction of 2 or more hormones may be involved according to arguments by Autio and Bramlage (1986). On the other hand this decline in chilling sensitivity may be related to one of the many physiological and biochemical changes that may occur during the initiation of tomato ripening. Since the fruits were ripened off the plant in this investigation, the decline might have been related to temperature conditioning, as has been reported for grapefruit by Hatton and Cubbedge (1982).

Table 1. Severity of pitting, decay and resistance to chilling injury of table-ripe processing and non-processing tomato cultivars kept at $7^{\circ} \mathrm{C}$ for 21 days (SRI) and upon transfer to $20^{\circ} \mathrm{C}$ for 1 day (SR1) or 3 days (SR3), respectively

\begin{tabular}{|c|c|c|c|c|c|c|c|}
\hline \multirow[t]{2}{*}{ Cultivar } & \multicolumn{3}{|c|}{ Pitting ${ }^{2}$} & \multicolumn{3}{|c|}{ Decay $^{2}$} & \multirow{2}{*}{$\begin{array}{l}\text { Resistance to } \\
\mathrm{Cl}^{\mathrm{Y}}\end{array}$} \\
\hline & SR1 & SR2 & SR3 & SR1 & SR2 & SR3 & \\
\hline \multicolumn{8}{|l|}{ Processing } \\
\hline Dorado & $1.9 b$ & $2.6 \mathrm{~cd}$ & 3.8efgh & $0.0 \mathrm{a}$ & $0.0 \mathrm{a}$ & $2.4 \mathrm{bcd}$ & 8.9ef \\
\hline Advantage & $0.0 \mathrm{a}$ & $1.6 \mathrm{ab}$ & $2.6 \mathrm{~cd}$ & $0.0 \mathrm{a}$ & $0.0 \mathrm{a}$ & $2.8 \mathrm{bcde}$ & $9.0 f$ \\
\hline Peto 94 C & 3.9efgh & $4.9 \mathrm{ij}$ & $5.9 \mathrm{kl}$ & $1.6 \mathrm{abc}$ & $3.0 \mathrm{cde}$ & $6.0 \mathrm{gh}$ & $4.4 \mathrm{bc}$ \\
\hline Neema 1401 & $4.1 \mathrm{fgh}$ & $4.8 \mathrm{ij}$ & $6.0 \mathrm{kl}$ & $2.2 \mathrm{bc}$ & $3.6 \mathrm{cdef}$ & $6.2 \mathrm{gh}$ & $4.2 a b c$ \\
\hline Caraibe & 4.2ghi & $5.2 j$ & $6.7 \mathrm{~m}$ & $2.0 b c$ & 3.9def & $6.8 \mathrm{gh}$ & $2.0 \mathrm{a}$ \\
\hline Rio Grande & $2.0 \mathrm{bc}$ & $2.5 b c$ & 3.6efg & $0.0 \mathrm{a}$ & $1.3 a b c$ & $3.1 \mathrm{cde}$ & $8.8 \mathrm{ef}$ \\
\hline Donore & $1.9 b$ & $2.5 \mathrm{bc}$ & 3.3def & $0.0 \mathrm{a}$ & $0.0 \mathrm{a}$ & $2.8 \mathrm{bcde}$ & 8.8ef \\
\hline Cascade & $3.9 \mathrm{fgh}$ & 4.4hi & $6.21 \mathrm{~m}$ & $0.0 \mathrm{a}$ & $3.6 \mathrm{cdef}$ & $5.2 \mathrm{fgh}$ & 2.2ab \\
\hline \multicolumn{8}{|c|}{ Non-processing } \\
\hline Calypso & $3.6 \mathrm{gh}$ & $4.4 \mathrm{ijk}$ & $5.21 \mathrm{~m}$ & $0.0 \mathrm{a}$ & $1.2 a b$ & 4.2ef & $6.2 \mathrm{~cd}$ \\
\hline Floradade & $3.4 \mathrm{fgh}$ & 4.0hij & $5.0 \mathrm{klm}$ & $0.0 \mathrm{a}$ & $0.0 \mathrm{a}$ & 3.9def & 7.0def \\
\hline Floradel & 3.8hi & 4.6jkl & $5.7 \mathrm{mn}$ & $0.0 \mathrm{a}$ & $1.6 a b c$ & $5.0 \mathrm{fg}$ & 7.0def \\
\hline Early Set & $4.1 \mathrm{hij}$ & 3.9hi & $5.6 \mathrm{mn}$ & $1.6 \mathrm{abc}$ & $2.6 \mathrm{bcde}$ & $6.0 \mathrm{gh}$ & $4.1 \mathrm{abc}$ \\
\hline Star Pak & $2.0 \mathrm{bc}$ & $2.5 \mathrm{~cd}$ & 3.2efgh & $0.0 \mathrm{a}$ & $1.6 \mathrm{abc}$ & $3.6 \mathrm{cdef}$ & $9.1 f$ \\
\hline Carnival & $4.4 \mathrm{ijk}$ & $4.9 \mathrm{k}$ & $15.9 n$ & $1.7 \mathrm{bc}$ & $2.5 \mathrm{bcd}$ & $5.2 f g h$ & $4.0 a b c$ \\
\hline Walters & $0.0 \mathrm{a}$ & $1.6 \mathrm{ab}$ & $2.9 \mathrm{def}$ & $0.0 \mathrm{a}$ & $0.0 \mathrm{a}$ & $3.6 \mathrm{cdef}$ & $9.0 f$ \\
\hline Capitan & $4.4 \mathrm{ijk}$ & $5.0 \mathrm{klm}$ & $6.0 n$ & $1.9 b c$ & $2.9 \mathrm{cde}$ & $6.6 \mathrm{gh}$ & $4.4 b c$ \\
\hline$\overline{\operatorname{LSD}(0.05)}$ & 0.6 & 1.6 & 2.2 & & & & \\
\hline
\end{tabular}

$\bar{z}$ Pitting and decay were scored on a 8-point Hedonic scale $(0=$ no pitting or decay; $8=$ severe pitting and decay).

${ }^{\mathrm{Y}}$ Resistance to $\mathrm{Cl}$ was scored on a scale of $1=$ most susceptible and $10=$ most resistant 
Table 2. Changes in overall quality and degree of brown discolouration of table-ripe processing and non-processing tomato cultivars kept at $7^{\circ} \mathrm{C}$ for 21 days (SR1) and upon transfer to $20^{\circ} \mathrm{C}$ for 1 day (SR2) or 3 days (SR3), respectively

\begin{tabular}{|c|c|c|c|c|c|c|}
\hline \multirow[t]{2}{*}{ Cultivar } & \multicolumn{2}{|c|}{ Overall qualityz } & \multirow{2}{*}{$\begin{array}{c}\text { Decrease in } \\
\text { Quality (\%) } \\
\text { SR3 }\end{array}$} & \multicolumn{3}{|c|}{ Degree of brown discolouration $Y$} \\
\hline & SR1 & SR3 & & SR1 & SR2 & SR3 \\
\hline \multicolumn{7}{|l|}{ Processing } \\
\hline Dorado & $7.5 \mathrm{gh}$ & 4.3de & 42.7 & $0.0 \mathrm{a}$ & $0.0 \mathrm{a}$ & $0.0 \mathrm{a}$ \\
\hline Advantage & $7.5 \mathrm{gh}$ & $4.9 e$ & 34.7 & $0.0 \mathrm{a}$ & $0.0 \mathrm{a}$ & $0.0 \mathrm{a}$ \\
\hline Peto $94 \mathrm{C}$ & $4.9 \mathrm{e}$ & $2.1 a b c$ & 57.1 & $2.2 \mathrm{c}$ & $2.2 \mathrm{c}$ & $2.8 \mathrm{~cd}$ \\
\hline Neema 1401 & $4.5 \mathrm{de}$ & 2.0abc & 55.6 & $2.6 \mathrm{~cd}$ & $2.8 \mathrm{~cd}$ & $2.8 \mathrm{~cd}$ \\
\hline Caraibe & $4.1 \mathrm{de}$ & 1.9abc & 53.7 & $3.0 \mathrm{~cd}$ & $3.6 \mathrm{~d}$ & $3.9 \mathrm{~d}$ \\
\hline Rio Grande & $7.1 \mathrm{fgh}$ & 4.4de & 38.0 & $0.3 a$ & $0.7 a$ & $1.3 a b$ \\
\hline Donore & $7.7 \mathrm{~h}$ & $4.9 \mathrm{e}$ & 36.4 & $0.1 \mathrm{a}$ & $0.6 \mathrm{a}$ & $1.1 \mathrm{ab}$ \\
\hline Cascade & $5.0 \mathrm{e}$ & $1.8 a b c$ & 64.0 & $3.2 \mathrm{~cd}$ & $3.2 \mathrm{~cd}$ & $3.9 d$ \\
\hline \multicolumn{7}{|c|}{ Non-processing } \\
\hline Calypso & $5.0 \mathrm{e}$ & $2.4 b c$ & 52.0 & $1.5 b c$ & $1.5 b c$ & $2.1 \mathrm{be}$ \\
\hline Floradade & 4.6de & $2.7 \mathrm{c}$ & 41.3 & $1.1 \mathrm{abc}$ & $1.4 \mathrm{bc}$ & $1.9 b c$ \\
\hline Floradel & $4.4 \mathrm{de}$ & $2.3 a b c$ & 47.7 & $1.0 \mathrm{ab}$ & $1.5 b c$ & $2.1 \mathrm{be}$ \\
\hline Early Set & 4.0de & $1.4 a$ & 65.0 & $2.1 \mathrm{be}$ & 2.1 be & $2.9 \mathrm{~cd}$ \\
\hline Star Pak & $7.2 \mathrm{gh}$ & $5.8 \mathrm{ef}$ & 19.4 & $0.0 \mathrm{a}$ & $0.0 \mathrm{a}$ & $0.0 \mathrm{a}$ \\
\hline Carnival & $3.9 \mathrm{~d}$ & $1.6 a b c$ & 58.9 & 2.1 be & $2.5 \mathrm{~cd}$ & $3.1 \mathrm{~cd}$ \\
\hline Walters & $7.6 \mathrm{gh}$ & $6.2 f$ & 18.4 & $0.0 \mathrm{a}$ & $0.0 \mathrm{a}$ & $0.0 \mathrm{a}$ \\
\hline Capitan & $4.1 \mathrm{de}$ & $1.6 \mathrm{abc}$ & 60.9 & $2.5 \mathrm{~cd}$ & $3.1 \mathrm{~cd}$ & $3.1 \mathrm{~cd}$ \\
\hline LSD (0.05) & & 0.9 & & & 1.1 & \\
\hline
\end{tabular}

Z Overall quality was scored on an 8-point Hedonic scale $\left(0=\right.$ poor; $8=$ excellent quality). ${ }^{Y}$ Degree of brown discolouration, was measured subjectively on a 5 -point Hedonic scale ( $0=$ no brown discolouration; $5=$ above $75 \%$ brown discolouration)

Fruit from the various processing and non-processing tomato cultivars exhibited differences in sensitivity to chilling injury as shown in Tables 1 and 2. The variability in correlations among the measurement of chilling sensitivity within and among these tomato cultivars indicated that their physiological and horticultural response to chilling is complex. This is in agreement with Cabrera and Saltveit's (1992) argument in earlier studies which postulated that breeding to reduce chilling injury would necessitate the adoption of several approaches to encompass the diversity of the responses mentioned.

\section{Acknowledgment}

The authors wish to thank Mr. Sarran Harryram and Ms. Andrea Houston for their help in field work and typing of the manuscript, respectively. Many thanks to Caribbean Chemicals Company Limited and Wyatt Company Limited for supplying seeds.

\section{References}

Abou-Aziz, A.B., S.M. El-Nataway, F.K. Adel-Wahab and A.A. Kader, 1976. The effect of storage temperature on quality and decay percentage of 'Pairi' and 'Taimour' mango fruit. Sci. Hortic., 5: 6572.

Autio, W.R. and W.J. Bramlage, 1986. Chilling sensitivity of tomato fruits in relation to ripening and senescence. J. Amer. Soc. Hort. Sci., 111(2): 201-205.

Buescher, R.W. 1974. Quality changes in tomatoes as affected by low temperature storage of unripe fruit. Arkansas Farm Res., 23: 11-12.

Cabrera, R.M. and M.E. Saltveit Jr., 1992. Cucumber cultivars differ in their response to chilling temperatures. J. Amer. Soc. Hort. Sci., 117(5): 802-807.

Couey, H.M. 1982. Chilling injury of crops of tropical and sub-tropical origin. HortScience, 17: 162-165.
Hatton, T.T. and R.H. Cubbedge, 1982. Conditioning Florida grapefruit to reduce chilling injury during low temperature storage. J. Amer. Soc. Hort. Sci., 107: 57-60.

Hobson, G.E. 1981. The short-term storage of tomato fruit. J. Hortic. Sci., 56: 363-368.

Kader, A.A. and L.L. Morris, 1975. Amelioration of chilling injury symptoms on tomato fruits. HortScience, 10: 324 (Abstr.)

King, M.M. and P.M. Ludford, 1983. Chilling injury and electrolyte leakage in fruit of different tomato cultivar. J. Amer. Soc. Hort. Sci., 108: 74-77.

Lipton, W.J. 1978. Chilling injury of 'Honey Dew' muskmelons. Symptoms and relation to degree of ripeness at harvest. HortScience, 13: 45-46.

McColloch, L.P. and J.T. Worthington, 1952. Low temperature as a factor in the susceptibility of mature-green tomatoes to Alternaria rot. Phytopath., 42: 425-427.

Mohammed, M. and J.K. Brecht, 1999. Influence of ethylene treatments on the alleviation of chilling injury in mango (cv. Palmer). Acta Hortic., 509(1): 437-446.

Mukerjee, R.K. and R.B. Srivastava, 1979. Increasing the storage life of mangoes (Mangifera indica, L.) by lowering the critical temperature. Prog. Hort., 10(4): 63-69.

Nazeeb, M. and W.J. Broughton, 1978. Storage conditions and ripening of papaya 'Bentong and Taiping'. Sci. Hortic., 9: 265-277.

Saltveit, M.E., Jr. and L.L. Morris, 1990. Overview of chilling injury of horticultural crops, p. 1-14. In: C.Y. Wang (ed.) Chilling injury of horticultural crops. CRC Press, Boca Raton, Fla.

Thorne, S.N. and S. Alvarez, 1982. The effect of irregular storage temperatures on firmness and surface colour in tomatoes. J. Sci. Food Agric., 33: 671-676.

United Fresh Fruit and Vegetable Assn. 1975. Colour classification requirements in tomatoes. USDA Visual Aid TM-L-1. The John Henry Co., Lansing, Mich. 